\title{
Hexavalent Chromium in Tannery Solid Waste Based Poultry Feed in Bangladesh and Its Transfer to Food Chain
}

\author{
L. T. Mazumder ${ }^{1}$, S. Hasan ${ }^{1, *}$ and M. L. Rahman ${ }^{1}$ \\ ${ }^{I}$ (Department of Environmental Science, Independent University, Bangladesh, Bangladesh)
}

\begin{abstract}
Solid tannery waste from the Hazaribagh area in the outskirts of Dhaka city is used as the principal component of poultry feed, fish feed and fertilizers. Although total chromium content in tannery waste based poultry feed has been determined previously, no studies appear to have been made on the hexavalent chromium which is much more toxic than trivalent chromium and is a carcinogen. The USEPA method 3060A which involves alkaline digestion to prohibit inter-conversion of $\mathrm{Cr}$ (III) and $\mathrm{Cr}$ (VI) has been used to solubilize chromium from the samples. The well-established spectrophotometric method (EPA method 7196A) has been employed to measure $\mathrm{Cr}(\mathrm{VI})$ concentrations at $540 \mathrm{~nm}$ in different samples. A total of 42 samples including solid leather waste, poultry feed, chicken livers and eggs were analyzed. Out of 5 skin-cuts two have shown the presence of $\mathrm{Cr}(\mathrm{VI})$. The amounts of $\mathrm{Cr}(\mathrm{VI})$ that have been found in 6 of the poultry samples are significantly higher (except one) than those found in skin-cut samples. About $25 \%$ of the chicken liver has been found to contain $\mathrm{Cr}$ (VI). It is reasonable to assume that this has come from the poultry feed.
\end{abstract}

Keywords: Hexavalent chromium, tannery waste, poultry feed, Hazaribagh, EPA method 3060A and 7196A.

\section{Introduction}

The tanning industries of Hazaribagh area of Dhaka city are processing some 220 metric tons of hide a day with an associated release of $600-1000 \mathrm{~kg}$ of solid waste for each ton of processed hide [2]. At present, several large mills and many locals are involved in converting the solid wastes into protein-concentrate for mixing into poultry feed. Each large mill produces 200-250 tons of protein-concentrate per day [2].

Previously, large quantities of solid leather wastes were disposed of through landfills. This caused leaching out of chromium in the soil making it unfit for cultivation and other uses. Increased environmental restrictions and escalating landfill costs have encouraged the leather industry to develop cleaner technology by minimizing wastes generated and maximizing those reused. Hence, to reduce the landfill problem of chrome leather pieces, they are currently being used as either poultry feed or fertilizer. It is stated in one of the leading newspapers [3] that previously, tannery owners had to spend around BDT 1,000 each time they cleaned the waste but now, they are earning a fortune by selling wastes. Every day the owners sell 1-5 metric tons of tannery waste to traders. It is found that an owner of a Hazaribagh feed factory pays BDT 5 to 15 lakh in advance to collect skin-cut waste per annum [3]. After the collection of solid wastes, they boil the waste in big containers and dry it in the sun for five days. They sell the dried products to middlemen. They are capable of supplying up to $200 \mathrm{~kg}$ of raw products every day to the middlemen, who grind and sell those to fish and poultry feed factories. There are around 10 grinding mills in Hazaribagh area. A middleman sells around five metric tons of meat bone every day to various feed factories and retailers across the country. It is also reported that traders used to import a kilogram of meat bone at BDT 10 five years ago, which is now BDT 35 a $\mathrm{kg}$ [3]. On the other hand, meat bone made of tannery waste only costs BDT 20 to 22 per kg. Moreover, compared to the imported protein, only half the amount of skin-cut meat bone is required to manufacture one $\mathrm{kg}$ of feed [3]. Generally, one $\mathrm{kg}$ poultry feed uses $60 \%$ meat bone, $40 \%$ other ingredients like soya oil cake, ground rice and dry fish [3]. Thus, almost all the feed factories prefer tannery waste-turned meat bone to imported protein. At present, there are around 70 big and medium and 300 small feed factories in the country [2].

A study conducted in 2007 by Dhaka University and Bangladesh Council for Scientific and Industrial Research (BCSIR) revealed higher amounts of chromium in eggs and poultry meat than the tolerable limit. The maximum chromium content of solid waste was found to be $3.2037 \%$ [7]. Data analysis showed that boiling and drying treatments brought no significant change in chromium levels in collected samples. Proteinconcentrate sampled from a feed mill at Hazaribagh produced chromium concentration of $2.4901 \%$ as element [7]. Cadmium, lead, arsenic, and mercury contents of all samples were also determined. The results obtained here (please delete the word) are in conformity with the fact that $80 \%$ tanneries of Bangladesh practice chrome tanning procedure. Whereas chromium has been found in percentage level, other heavy metals are at parts per million (ppm) levels [7].

The factors that possibly turn up the oxidation of the trivalent chromium into the hexavalent form are as follows:

- Quality of chemicals, especially, chrome tanning agents, 
- Photo-ageing by air subjected to UV lights,

- Oxidation by air favored at high $\mathrm{pH}$,

- High temperature (like heating at $80^{\circ} \mathrm{C}$ ),

- Unsuitable storage conditions, and

- Influence of natural fat.

Oxidation of $\mathrm{Cr}$ (III) into $\mathrm{Cr}$ (VI) normally occurs in presence of strong oxidation agent in acid environment. But it can also take place in presence of mild oxidizing agents at high $\mathrm{pH}$. In leather processing, liming, pickling and neutralization are the stages when there are possibilities of occurring such conditions [6].

The supposed mechanism of $\mathrm{Cr}$ (VI) formation in leather has been proposed by several authors [5, 6]. This mechanism is connected with the oxidation of unsaturated fats by free radicals that are formed by UV light from a molecule whose normal covalent bond is split to create two unstable moieties. These free radicals react with oxygen, developing very reactive derivates (please delete the word) derivatives such as, peroxides, and radicals such as, $\mathrm{HO}^{\circ}, \mathrm{RO}^{\circ}$ and $\mathrm{ROO}^{\circ}$ which are strong oxidants. Probably this is the reason for chromium oxidation in light [6].

It has also been observed [6] that the more the trivalent chromium used and higher the ironing temperature applied, the higher the hexavalent chromium level. Ferreira et al. [5] identified the increased levels of $\mathrm{Cr}(\mathrm{VI})$ in the ash from solid tannery waste or leather samples as depending on the temperature and the holding time after heating in the $300-1000^{\circ} \mathrm{C}$ ranges. The leather ashes showed higher $\mathrm{Cr}$ (VI) levels for burning temperatures $<500^{\circ} \mathrm{C}$ and $>800^{\circ} \mathrm{C}$. The longer the holding time, the less $\mathrm{Cr}(\mathrm{VI})$ was detected.

Poor storage conditions lead to formation of $\mathrm{Cr}$ (VI) from $\mathrm{Cr}$ (III) in skin-cuts and leather. The influence of the relative humidity of air might be a reason of $\mathrm{Cr}(\mathrm{VI})$ formation in chrome tanned leathers during storage. It was found that $\mathrm{Cr}(\mathrm{VI})$ can be formed if the relative humidity of the air is under 35\% [6].

The chemical and toxicological behaviors of chromium salts depend on the oxidation state of chromium. The USEPA has listed chromium as one of 129 priority pollutants and it is considered as one of the most noxious heavy metals. Chromium can exist in many oxidation states but its most stable forms are $\mathrm{Cr}$ (III) and $\mathrm{Cr}$ (VI). Whereas $\mathrm{Cr}$ (III) is useful and essential in small amounts for human health and its deficiency causes certain diseases, $\mathrm{Cr}$ (VI) is highly toxic and responsible for health hazards like mutation, cancer and cell damage [1].

From the point of view of public health, it would be much more pertinent and important to know how much $\mathrm{Cr}(\mathrm{VI})$ is there in the feed and how much is going into chicken and eggs. The present work has therefore been devoted entirely to the determination of $\mathrm{Cr}(\mathrm{VI})$ in protein-concentrate, poultry feed, chicken and eggs. The paper focuses on to study the hexavalent chromium status of protein-concentrate at every detail right from the source (e.g. wet blue leather, shaving and crusted parts of leather) to the final product (feed in the market). The possibilities of $\mathrm{Cr}(\mathrm{VI})$ entering the food chain through chickens and eggs were also examined.

\section{Methodology}

\subsection{Study area}

Hazaribagh is situated on the south-west part of the capital Dhaka with an area of 3.58 square kilometer. It is located between $23^{\circ} 43.85^{\prime}$ to $23^{\circ} 44.05^{\prime} \mathrm{N}$ latitude and $90^{\circ} 21.85^{\prime}$ to $90^{\circ} 22.15^{\prime} \mathrm{E}$ longitude [7].

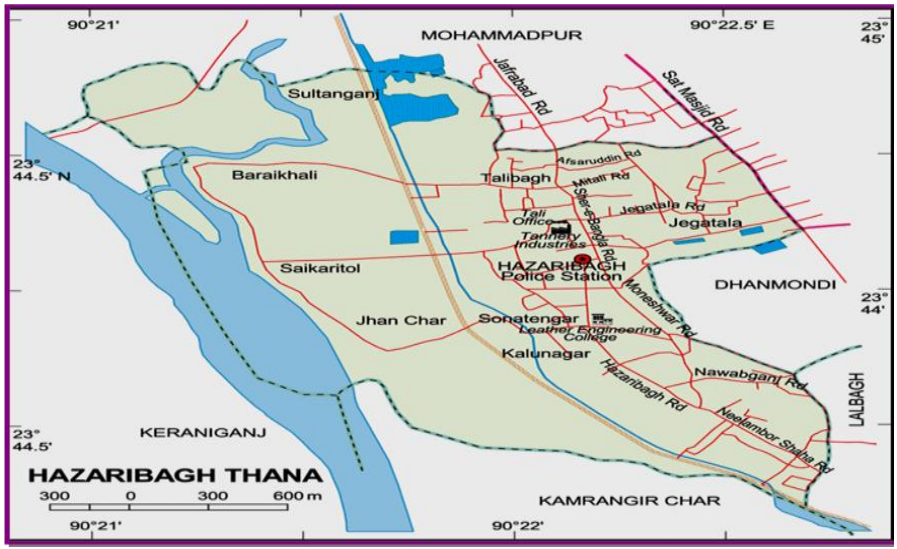

Figure 1: Map of Hazaribagh Area

\subsection{Sampling and sample size}

For the research purpose, the protein-concentrate production processes practiced at Hazaribagh were first surveyed and observed. In addition, locals of each sampling area were interviewed. The in-depth interview 
and the personal observation helped to know the amount of tannery solid waste, the frequency of application of skin-cut wastes in making feeds, feed producers, and the distribution of feeds etc.

Overall 42 samples were collected in pre-cleaned plastic or glass sample bottles. Samples were collected from different spots at Hazaribagh and from its adjacent areas. These areas were the neighborhood of Hazaribagh Police Station, feed mills at Hazaribagh, Hazaribagh bazaar, New-market bazaar and Nimtoli poultry market. Fifteen chickens and seven eggs were randomly sampled from these areas where local feed producers of Hazaribagh usually supply chicken feed to different poultry sellers at cheap rates. In addition, chicken age and body weight were considered during sampling. This was done because with time there is a possibility of occurrence of $\mathrm{Cr}$ (VI) into the fleshy parts of chicken through biotransformation and bioaccumulation from the poultry feed. All the samples were categorized into four different groups as mentioned in table 1:

Table 1: Sample categorization with characteristics

\begin{tabular}{|c|c|c|c|c|}
\hline Groups & $\begin{array}{c}\text { Sample } \\
\text { no. }\end{array}$ & $\begin{array}{l}\text { Sample Categorization } \\
\text { (Solid waste) }\end{array}$ & Characteristics & Sources \\
\hline \multirow{5}{*}{ Group A } & 1 & Wet blue skin-cuts & Fleshing part & \multirow{5}{*}{$\begin{array}{c}\text { Tannery industries in } \\
\text { Gajmahal, Jhan Char, } \\
\text { and near Hazaribagh } \\
\text { Police Station. }\end{array}$} \\
\hline & 2 & Wet blue skin-cuts & $\begin{array}{l}\text { Mixture of different parts } \\
\text { (dumped in open space) }\end{array}$ & \\
\hline & 3 & $\begin{array}{l}\text { Faded greenish-blue } \\
\text { skin-cuts }\end{array}$ & $\begin{array}{l}\text { Mixture of different parts } \\
\text { (dumped in open space) }\end{array}$ & \\
\hline & 4 & Skin-cuts & $\begin{array}{l}\text { Mixture of different parts } \\
\text { (stored inside the room) }\end{array}$ & \\
\hline & 5 & $\begin{array}{l}\text { Faded greenish-blue } \\
\text { skin-cuts }\end{array}$ & Shaving (lower split) & \\
\hline \multirow{15}{*}{ Group B } & 6 & Raw feed & $\begin{array}{l}\text { Solid wastes boiled }+ \\
\text { dried in open space }\end{array}$ & $\begin{array}{c}\text { In front of Feed mill ' } a \text { ' } \\
\text { at Hazaribagh }\end{array}$ \\
\hline & 7 & Raw feed & $\begin{array}{l}\text { Solid wastes boiled }+ \\
\text { dried in open space }\end{array}$ & $\begin{array}{l}\text { Feed mill 'b' at } \\
\text { Hazaribagh }\end{array}$ \\
\hline & 8 & Raw feed & $\begin{array}{l}\text { Ground mixture after } \\
\text { sun-dried }\end{array}$ & Local Producer \\
\hline & 9 & Processed feed & Processed feed & Local Producer \\
\hline & 10 & Processed feed & Processed feed & Hazaribagh bazaar \\
\hline & 11 & Processed feed & Processed feed & Hazaribagh bazaar \\
\hline & 12 & Processed feed & $\begin{array}{l}\text { Processed feed with } \\
\text { vegetable mix }\end{array}$ & New-market bazaar \\
\hline & 13 & Processed feed & Processed feed & New-market bazaar \\
\hline & 14 & Processed feed & Processed feed & Hazaribagh bazaar \\
\hline & 15 & Processed feed & Processed feed & Nimtoli poultry market \\
\hline & 16 & Processed feed & Processed feed & Nimtoli poultry market \\
\hline & 17 & Processed feed & $\begin{array}{l}\text { Processed feed with } \\
\text { vegetable mix }\end{array}$ & Nimtoli poultry market \\
\hline & 18 & Processed feed & $\begin{array}{l}\text { Processed feed with } \\
\text { vegetable mix }\end{array}$ & Nimtoli poultry market \\
\hline & 19 & Processed feed & $\begin{array}{l}\text { Processed feed with } \\
\text { vegetable mix }\end{array}$ & Nimtoli poultry market \\
\hline & 20 & Processed feed & Processed feed & Nimtoli poultry market \\
\hline \multirow{4}{*}{$\begin{array}{c}\text { Group C } \\
\text { [Chickens } \\
\text { (both broiler \& } \\
\text { layer)] }\end{array}$} & $21-22$ & Liver & $\begin{array}{l}\text { Age: } 2-3 \text { weeks } \\
\text { Weight: } 625-750 \mathrm{~g}\end{array}$ & \multirow{2}{*}{ Nimtoli poultry market } \\
\hline & $23-27$ & Liver & $\begin{array}{c}\text { Age: } 6-8 \text { weeks } \\
\text { Weight: } 1500-1850 \mathrm{~g}\end{array}$ & \\
\hline & $28-30$ & Liver & $\begin{array}{c}\text { Age: } 2-3 \text { weeks } \\
\text { Weight: } 580-820 \mathrm{~g}\end{array}$ & \multirow{2}{*}{ Hazaribagh bazaar } \\
\hline & $31-35$ & Liver & $\begin{array}{c}\text { Age: } 6-8 \text { weeks } \\
\text { Weight: } 1400-1750 \mathrm{~g}\end{array}$ & \\
\hline $\begin{array}{l}\text { Group D } \\
\text { [Eggs (both } \\
\text { broiler \& } \\
\text { layer)] }\end{array}$ & $36-42$ & Albumen \& Yolk & Brown eggs & Hazaribagh bazaar \\
\hline
\end{tabular}

\subsection{Sample digestion (USEPA method 3060A)}

Alkaline digestion is the recommended method to solubilize both water-insoluble and water soluble $\mathrm{Cr}$ (VI) compounds in solid waste samples, where there is the possibility of conversion of $\mathrm{Cr}$ (VI) into $\mathrm{Cr}$ (III). The 
$\mathrm{pH}$ of the digestate was carefully adjusted during the digestion procedure. The sample was digested using $0.28 \mathrm{M}$ $\mathrm{Na}_{2} \mathrm{CO}_{3} / 0.5 \mathrm{M} \mathrm{NaOH}$ solution and heating at $90-95^{\circ} \mathrm{C}$ for 60 minutes to dissolve the $\mathrm{Cr}(\mathrm{VI})$ and stabilize it against reduction to $\mathrm{Cr}$ (III) [8]. EPA Method 7196A is the most applicable and reliable method for analysis of $\mathrm{Cr}$ (VI) solubilized in the alkaline digestate. It is highly selective for $\mathrm{Cr}$ (VI) and little interferences are encountered when it is used on alkaline digestates [9].

\subsection{Reagents used}

Nitric acid, sodium carbonate, sodium hydroxide, magnesium chloride, and phosphate buffer $\left(\mathrm{K}_{2} \mathrm{HPO}_{4}\right.$. $\mathrm{KH}_{2} \mathrm{PO}_{4}$ ) were all of analytical grade. All the chemicals have been purchased from Merck, Germany and used without further purification.

Digestion solutions were prepared by dissolving $20.0 \pm 0.05 \mathrm{~g} \mathrm{NaOH}$ and $30.0 \pm 0.05 \mathrm{~g} \mathrm{Na}_{2} \mathrm{CO}_{3}$ in reagent water in a one-liter volumetric flask and diluted to the mark. The $\mathrm{pH}$ of the digestion solution was checked before using. The $\mathrm{pH}$ was 11.5 or greater.

The spiking solution $[1000 \mathrm{mg} / \mathrm{L} \mathrm{Cr}(\mathrm{VI})]$ was prepared by dissolving $2.829 \mathrm{~g}$ of dried $\left(105^{\circ} \mathrm{C}\right)$ $\mathrm{K}_{2} \mathrm{Cr}_{2} \mathrm{O}_{7}$ in reagent water in a one-liter volumetric flask and diluting upto the mark.

\subsection{Procedures (EPA methods 3060A and 7196A)}

$2.5 \pm 0.10 \mathrm{~g}$ of the sample was placed into a clean and labeled $250 \mathrm{~mL}$ digestion vessel. $50 \mathrm{~mL} \pm 1 \mathrm{~mL}$ of digestion solution was added to each sample using a volumetric flask, and also approximately $400 \mathrm{mg}$ of $\mathrm{MgCl}_{2}$ and $0.5 \mathrm{~mL}$ of $1.0 \mathrm{M}$ phosphate buffer were added. Temperature of each heating device used in the alkaline digestion was adjusted to $90-95^{\circ} \mathrm{C}$ by preparing and monitoring a temperature blank. Samples were then continuously stirred (unheated) for at least five minutes using an appropriate stirring device. After that the sample solutions were heated at $80-100^{\circ} \mathrm{C}$ for at least 60 minutes with continuous stirring. Next, the heated solutions were gradually cooled down to room temperature. Then, the samples were transferred quantitatively to the centrifuge tubes. After centrifuge, the supernatant and the rinses were transferred to a clean $250-\mathrm{mL}$ vessel [filtration was done if necessary after centrifuge]. An appropriate stirring device was placed into the sample digest beaker, and then the vessel was placed on a stirrer, and, with constant stirring, 5.0 M nitric acid solution was added slowly to the beaker drop wise. The $\mathrm{pH}$ of the solution was adjusted to $7.5 \pm 0.5$. Sulfuric acid $\left(\mathrm{H}_{2} \mathrm{SO}_{4}\right)$ was then added to adjust the $\mathrm{pH}$ to 1.5-2.5. Different volumes of the extract were transferred to $100-\mathrm{mL}$ volumetric flasks. $2.0 \mathrm{~mL}$ of 1,5-diphenylcarbazide was added to the solution. Then, five to ten minutes were needed to wait for full color development. Finally, an appropriate portion of the solution was transferred to a quartz one-cm absorption cell and its absorbance was measured at $543 \mathrm{~nm}$ in a Hach DR/4000 model UVVisible spectrophotometer $[8,9]$.

\subsection{Inter-conversion of $\mathrm{Cr}(\mathrm{VI})$ and $\mathrm{Cr}$ (III)}

It is known that $\mathrm{Cr}(\mathrm{VI})$ is easily reduced to $\mathrm{Cr}$ (III) in a reducing atmosphere under acidic conditions. Presumably this is the reason why the EPA has recommended alkaline digestion to be followed for $\mathrm{Cr}$ (VI) estimation. In order that $\mathrm{Cr}$ (III) is not oxidized to $\mathrm{Cr}$ (VI), addition of $\mathrm{Mg}$-salts has been suggested. Nevertheless, questions have been raised as to whether the method underestimates or overestimates the in-situ values of $\mathrm{Cr}$ (VI) in soil samples for which the methods have been developed [9]. In fact, it is not possible to arrest the interconversion completely by controlling the $\mathrm{pH}$, because, after alkaline digestion, the $\mathrm{pH}$ has to be brought back to 1.5-2.5, the only range at which the colored complex is stable. The step of addition of $\mathrm{Mg}$-salt has also been criticized.

A standard method of checking whether the result of analysis is reliable is spiking. In view of the inherent difficulty in controlling the oxidizing or reducing atmosphere in the samples and in view of the importance of analysis of $\mathrm{Cr}$ (VI) which is highly toxic to human health, the EPA seems to have been quite liberal in accepting the results of spiking. In the USEPA statement of work [10] "the method specified criteria for the matrix spike recovery is greater than or equal to $75 \%$ and less than or equal to $125 \%$ ". In USEPA contract laboratory program guidelines [10], it is stated that "if the matrix spike recovery is $30-75 \%$ and the sample results are above the minimum detection limit, then the results are qualified". The samples that are being studied here are rather biological in nature, for example, chicken and eggs. It is expected that these samples will be more reducing than the soil samples. Thus, the extended range of spike recovery is expected to be applicable.

\subsection{Interferences}

The chromium (VI) reaction with diphenylcarbazide is usually free from interferences [8]. However, certain substances may interfere if the chromium (VI) concentration is relatively low. Hexavalent molybdenum and mercury salts also react to form color with the reagent; however, the red-violet intensities produced are much lower than those for chromium at the specified $\mathrm{pH}$. Concentrations of up to $200 \mathrm{mg} / \mathrm{L}$ of molybdenum and 
mercury can be tolerated. Vanadium interferes strongly, but concentrations up to 10 times that of chromium will not cause trouble.

Iron in concentrations greater than one $\mathrm{mg} / \mathrm{L}$ may produce a yellow color, but the ferric iron color is not strong and difficulty is not normally encountered if the absorbance is measured photometrically at the appropriate wavelength. As far as is known about the presence of these interfering metals in the kind of samples being analyzed here [8], they should pose no problem.

\subsection{Spectrophotometric calibration}

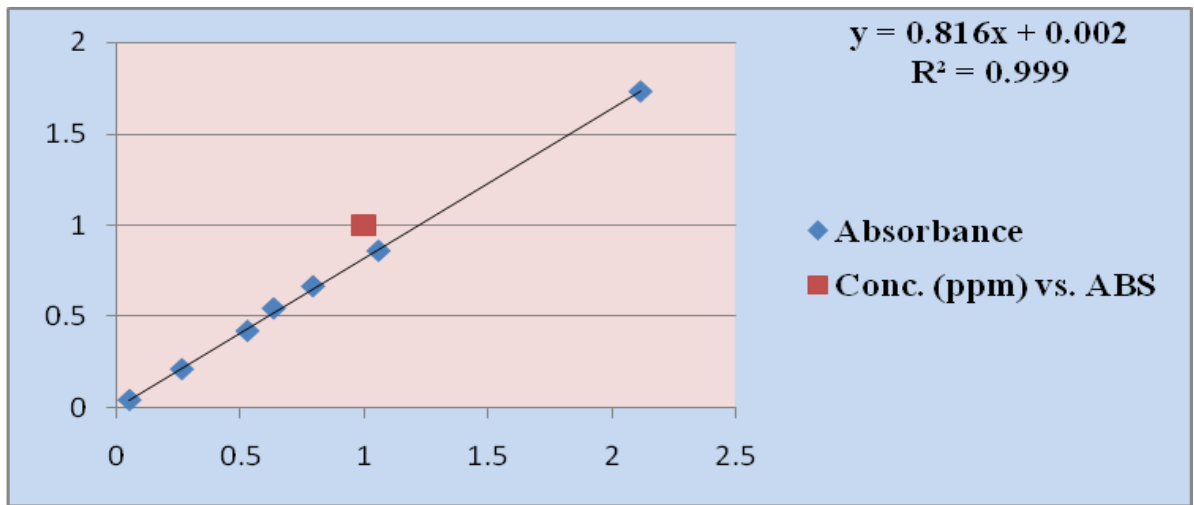

Figure 3: Calibration curve for standard solution [Cr (VI) present in $\left.\mathrm{K}_{2} \mathrm{Cr}_{2} \mathrm{O}_{7}\right]$

It is evident that the graph follows the Beer-Lambert law quite closely, the $\mathrm{R}^{2}$ value being 0.999 . The value of the extinction coefficient has been found to be 42,428 in excellent agreement with the literature values. In addition, Sandell's sensitivity has been found to be $1.2 \mathrm{ppb} \mathrm{cm}^{-2}$ and the detection limit $0.0017 \mathrm{ppm}$.

\section{Results}

Using the USEPA methods no. 3060A (alkali digestion) and 7196A (spectrophotometry), attempts have been made to determine hexavalent chromium in the following four groups of samples.

\subsection{Reproducibility of the results}

The Microsoft Excel Program has been used to calculate the standard deviation for each sample that gave measurable readings. It would be found that except two samples, no's 10 and 34' where the Cr (VI) concentrations were rather low, the error values are within $15 \%$. The present values can be compared with those obtained by Hossain et al. [7] who measured the total $\mathrm{Cr}$ content in egg samples by using atomic absorption spectrophotometry. Their errors ranged from $11 \%$ to $44 \%$.

The calibration was checked every now and then and the absorption coefficient $(€)$ values were found to vary over a range. For the calculation of the concentrations, the most recent calibration graphs were used. Although the most quoted absorption coefficient is $40,000 \mathrm{~L} \mathrm{~mol}^{-1} \mathrm{~cm}^{-1}$, values as low as 26,000 and as high as 90600 have also been reported in the literature [10]. The charge transfer complex that is supposed to form on addition of diphenylcarbazide to $\mathrm{Cr}(\mathrm{VI})$ is quite sensitive to factors like $\mathrm{pH}$ and freshness of the reagent.

\subsection{Reliability of the results}

Spiking has been used to test whether the results obtained were reliable. The spike recovery percentage is $84 \%$ for poultry feed, $74.89 \%$ for chicken and zero for eggs. According to the criteria fixed by the USEPA [10], the method of analysis is valid for the groups A to C, but not for D.

The consolidated results for each group are given here in tables 2,3 , and 4 .

Table 2: Amount of $\mathrm{Cr}$ (VI) in tannery solid waste

\begin{tabular}{|c|c|c|c|}
\hline & Sample no. & Characteristics & Amount of Cr (VI) in mg/kg \\
\cline { 2 - 4 } & 1 & Fleshing part & nd \\
\cline { 2 - 4 } $\begin{array}{c}\text { Group A } \\
\text { (Solid leather } \\
\text { waste) }\end{array}$ & 2 & $\begin{array}{c}\text { Mixture of different parts } \\
\text { (dumped in open space) }\end{array}$ & nd \\
\cline { 2 - 4 } & 3 & $\begin{array}{c}\text { Mixture of different parts } \\
\text { (dumped in open space) }\end{array}$ & $\mathbf{0 . 1 9 5 0} \pm \mathbf{0 . 0 1 6 2}$ \\
\cline { 2 - 5 } & 4 & $\begin{array}{c}\text { Mixture of different parts } \\
\text { (stored inside the room) }\end{array}$ & $\mathbf{0 . 1 2 5 8} \pm \mathbf{0 . 0 1 2 7}$ \\
\cline { 2 - 4 } & 5 & Shaving (upper split) & nd \\
\hline
\end{tabular}

nd $=$ Not detectable 
Table 3: Amount of $\mathrm{Cr}$ (VI) in poultry feeds

\begin{tabular}{|c|c|c|c|c|}
\hline \multirow{16}{*}{$\begin{array}{c}\text { Group B } \\
\text { (Poultry } \\
\text { Feeds) }\end{array}$} & Sample no. & Categorization & $\begin{array}{c}\text { Amount of } \mathrm{Cr}(\mathrm{VI}) \text { in } \\
\mathrm{mg} / \mathrm{kg}\end{array}$ & $\begin{array}{c}\text { Spike } \\
\text { Recovery }\end{array}$ \\
\hline & 6 & Solid wastes boiled + dried in open space & nd & \multirow{15}{*}{$84 \%$} \\
\hline & 7 & Solid wastes boiled + dried in open space & $0.2714 \pm 0.0394$ & \\
\hline & 8 & Solid wastes boiled + dried in open space & $0.4184 \pm 0.0411$ & \\
\hline & 9 & Processed feed & $0.4598 \pm .0 .0297$ & \\
\hline & 10 & Processed feed & $0.0740 \pm 0.0240$ & \\
\hline & 11 & Processed feed & nd & \\
\hline & 12 & Processed feed with vegetable mix & nd & \\
\hline & 13 & Processed feed & nd & \\
\hline & 14 & Processed feed & nd & \\
\hline & 15 & Processed feed & nd & \\
\hline & 16 & Processed feed & $0.4234 \pm 0.0342$ & \\
\hline & 17 & Processed feed with vegetable mix & $0.6062 \pm 0.0339$ & \\
\hline & 18 & Processed feed with vegetable mix & nd & \\
\hline & 19 & Processed feed with vegetable mix & nd & \\
\hline & 20 & Processed feed & nd & \\
\hline
\end{tabular}

nd $=$ not detectable

Table 4: Amount of $\mathrm{Cr}$ (VI) in chicken liver

\begin{tabular}{|c|c|c|c|c|c|}
\hline \multirow{16}{*}{$\begin{array}{c}\text { Group C } \\
\text { [Chickens } \\
\text { (both broiler \& } \\
\text { layer)] }\end{array}$} & $\begin{array}{c}\text { No. of } \\
\text { Samples }\end{array}$ & $\begin{array}{c}\text { Age } \\
\text { (in weeks) }\end{array}$ & $\begin{array}{l}\text { Body weight } \\
\text { (in gm) (g) }\end{array}$ & $\begin{array}{c}\text { Concentration of } \mathrm{Cr}(\mathrm{VI}) \\
\text { in } \mathrm{mg} / \mathrm{kg}\end{array}$ & $\begin{array}{c}\text { Spike } \\
\text { Recovery }\end{array}$ \\
\hline & 21 & 2 & 630 & nd & \multirow{15}{*}{$74.89 \%$} \\
\hline & 22 & 2.4 & 720 & nd & \\
\hline & 23 & 6 & 1500 & nd & \\
\hline & 24 & 7 & 1650 & nd & \\
\hline & 25 & 7 & 1630 & nd & \\
\hline & 26 & 8 & 1790 & $0.0940 \pm 0.0147$ & \\
\hline & 27 & 8 & 1830 & nd & \\
\hline & 28 & 3 & 730 & nd & \\
\hline & 29 & 3 & 760 & nd & \\
\hline & 30 & 3 & 600 & nd & \\
\hline & 31 & 7 & 1520 & $0.1430 \pm 0.0174$ & \\
\hline & 32 & 8 & 1720 & nd & \\
\hline & 33 & 8 & 1750 & $0.1770 \pm 0.0247$ & \\
\hline & 34 & 8 & 1700 & $0.0860 \pm 0.0280$ & \\
\hline & 35 & 8 & 1695 & nd & \\
\hline
\end{tabular}

nd= not detectable

\section{Discussions}

It is seen from Table 2 that wet-blue skin-cuts and greenish-blue skin-cuts, sample no's 3 and 4 contain $\mathrm{Cr}$ (VI). The samples were chosen randomly and their history was unknown. They could have come from vegetable tanning or from chrome tanning industry. No chromium is expected from vegetable tanning but even with chrome tanning the presence of $\mathrm{Cr}(\mathrm{VI})$ is unexpected, because in a tanning process the skins and hides are treated with solutions of basic chromium sulphate (BCS) which is $\mathrm{Cr}$ (III) and not $\mathrm{Cr}$ (VI). The presence of $\mathrm{Cr}$ (VI) is not, therefore, easily explained. However, reasonable explanations can be put forward in the following way:

(i) $\quad \mathrm{Cr}(\mathrm{VI})$ was present as an impurity in the basic chromium sulphate

(ii) $\quad \mathrm{Cr}(\mathrm{VI})$ was formed during storage and the process of tanning

(iii) Combination of both (i) and (ii)

Various overseas companies including two local ones supply basic chromium sulphate to leather industries. Previously, dichromate had been used as a source of $\mathrm{Cr}$ (III). Although majority of the medium and large leather processing units manufacture wet blue products for export, the small ones produce low grade finished leather for domestic market or sometimes act as suppliers to big firms. As cost of the chemicals is an important concern, the presence of $\mathrm{Cr}(\mathrm{VI})$ as an impurity cannot be ruled out.

The favorable conditions under which $\mathrm{Cr}$ (III) can be oxidized to $\mathrm{Cr}$ (VI) have already been discussed. Thus if the chemicals are stored for a long time when the temperature goes up and especially if they are kept in the sun and exposed to UV radiation, there is the possibility of some $\mathrm{Cr}$ (III) being converted to $\mathrm{Cr}$ (VI). In the 
leather processing itself, some $\mathrm{Cr}$ (III) is oxidized to $\mathrm{Cr}$ (VI) at high $\mathrm{pH}$ values when alkali solution, sulphide etc. are added and thus, leather from other countries too contains some $\mathrm{Cr}$ (VI) [4].

Table 3 shows the results of poultry feed analysis. Cr (VI) is present in 6 of the 15 samples analyzed. Except for sample no. 10, the amounts of $\mathrm{Cr}(\mathrm{VI})(\mathrm{mg} / \mathrm{kg})$ in the remaining 5 samples are significantly higher than those found in skin-cut samples. Apparently, this is surprising because of the fact that skin-cuts are only one component of the poultry feed. So the proportion of $\mathrm{Cr}$ (VI) should be less. The production of poultry feed involves boiling of the skin-cuts at $80-100^{\circ} \mathrm{C}$ followed by sun drying for 5 days. This is the most favorable condition for the conversion of $\mathrm{Cr}$ (III) to $\mathrm{Cr}(\mathrm{VI})$. Poor storage condition may also aggravate the situation further.

Analysis of chicken liver for $\mathrm{Cr}$ (VI) has been shown in Table 4. Only 4 chickens out of 15 pieces have been found to contain hexavalent chromium in their livers. These chickens were bought from the local market on a random basis and were not fed upon the poultry feed containing $\mathrm{Cr}$ (VI) under controlled conditions. The number of chickens studied here may not be statistically significant, but even then more than $25 \%$ of the chickens contain $\mathrm{Cr}$ (VI) from 86 to $177 \mathrm{ppb}$ levels. It is reasonable to believe that $\mathrm{Cr}$ (VI) have come from the poultry feed produced from skin-cut tannery waste. The four chickens showing the presence of $\mathrm{Cr}$ (VI) were big in size (body weight: 1500-1790 g) and relatively old (7-8 weeks).

None of the egg samples had $\mathrm{Cr}(\mathrm{VI})$ at the detection level. Interestingly, the spiking recovery was also found to be negligible. The results obtained may indicate either (i) there was no detectable $\mathrm{Cr}$ (VI) in eggs (ii) it could not be measured by this method even if there were any. Hossain, et al. [7] found total chromium of $~ 1$ ppm in the chicken eggs. It is possible that eggs contain reducing species that convert $\mathrm{Cr}$ (VI) to $\mathrm{Cr}$ (III). In fact, the antioxidant, glutathione has its precursors in raw eggs and possibly prevents the formation of $\mathrm{Cr}$ (VI). The fact that spike recovery is $\sim 0 \%$ tends to suggest that the reducing atmosphere persists even when the egg is heated. The spike recovery values show a gradual decrease from $84 \%$ to $~ 0.00$, as the matrix shifts from poultry feed to chicken liver to egg. The internal atmosphere of living beings seems to be more reducing than that of non-living things.

Workers in the tannery industries are being exposed to $\mathrm{Cr}(\mathrm{VI})$ in more ways than one. While handling the chemicals and skin-cuts and preparing poultry feeds, they are being in dermal contact with $\mathrm{Cr}$ (VI). To bring all pieces of skin-cuts into sunshine uniformly, these pieces have to be turned upside down occasionally and this will throw some of them into the air and may enter the nostrils of the workers as particulate matter. Skin-cuts are also being used as fuels for boiling themselves for making feeds and also for cooking food. The persons involved in burning skin-cuts certainly breathe in a lot of particulate matter in the form of smoke which is likely to contain some $\mathrm{Cr}(\mathrm{VI})$. It has been reported that $\mathrm{Cr}$ (VI) as small as $0.000008 \mathrm{mg} / \mathrm{m}^{3}$ may cause respiratory trouble [1]. A report published in a local newspaper, the Daily Star quotes an inhabitant of the Hazaribagh area, saying "My niece has been suffering from asthma for the last two years while my nephew for one year" [3]. Dermal contact causes skin burning and other problems.

Apart from these direct exposures, more alarming is the situation when $\mathrm{Cr}$ (VI) enters the food chain. About $25 \%$ of the chickens analyzed here have been found to contain $\mathrm{Cr}$ (VI). Poultry feeds based on tannery solid waste are mostly produced in Dhaka and distributed throughout Bangladesh. If $\mathrm{Cr}$ (VI) is present in the same percentage of chicken all over Bangladesh, the hazard to public health is highly significant. As is well known, toxicity of $\mathrm{Cr}(\mathrm{VI})$ is enormous and its ill effects include cell damage, mutation and even cancer.

Hossain, et al. [7], have analyzed eggs from Dhaka and the adjoining districts such as Narayanganj, Gazipur, Munshiganj, Narshingdi, even Tangail and Mymensigh. In each case they have found total chromium in the range of 1-3 ppm. In our case, we have attempted to estimate $\mathrm{Cr}$ (VI) in only a few eggs of Dhaka city and the results have been negative. To be more confident many more samples should be investigated into and preferably with an alternative technique such as ion chromatography.

\section{Conclusion}

In the interest of public health, the production of poultry feed from the tannery waste should be banned. However, in a country like Bangladesh it would be very difficult to enforce this ban, because it is a profitable business and a large number of people derive direct or indirect benefit from it. Treating the waste and bringing the heavy metals to safe levels should be a better option. This would address the disposal problem of solid tannery waste to a considerable extent and the treated waste would find better use in the production of highly proteinaceous poultry feed and other useful byproducts like glue and sodium dichromate without any deleterious effect. 


\section{References}

[1]. Agency for Toxic Substances and Disease Registry (ASTDR), Toxicological profile for chromium, U.S. Department of Health and Human Services (Atlanta, GA, 2000).

[2]. (http://www.atsdr.cdc.gov/toxprofiles/tp7.pdf).

[3]. A.K. Alam, and M. Nizamul, Export of Bangladesh Leather: Present Performance and Future Prospect (Dhaka Export Promotion Bureau, 1998). (http://r0.unctad.org/trade_env/test1/meetings/bangkok5/b5Draft\%20case\%20study\%20Bangladesh.pdf).

[4]. H. Alam, Toxic Poultry Feed Poses Health Risk (Dhaka, July 24, 2010).

[5]. (http:// www.thedailystar.net/newDesign/news-details.php?nid=147986)

[6]. B. Basaran, M. Ulaş, O. B Behzat, and A. Aslan, Distribution of Cr (III) and Cr (VI) in chrome tanned leather, Indian Journal of Chemical Technology, 15, 2008, 511-514.

[7]. M.J. Ferreira, M.F. Almeida, and T. Pinto, Influence of Temperature and Holding Time on Hexavalent Chromium Formation during Leather Combustion, Journal of the Society of Leather Technologists \& Chemists, 83, 1999, 135.

[8]. C. Hauber and H. P. Germann, Investigations on a possible formation and avoidance of chromate in leather, World Leather, 13 (5), 2000,38 .

[9]. M. Hossain, M.M. Monir, T. Rezwan, A.M. Haque, U.L. Kazi, M.S. Islam, and S.F. Elahi, Heavy metal concentration in tannery solid wastes used as poultry feed and the ecotoxicological consequences, Bangladesh Journal of Science and Industrial Resources, 42(4), 2007, 397-416

[10]. USEPA, Method 7196A, Chromium Hexavalent (Colorimetric), Test Method for Evaluating Solid Waste, Physical/Chemical Methods (SW 846, $3^{\text {rd }}$ ed. Washington D.C. 1995b).

[11]. (http://www.epa.gov/osw/hazard/testmethods/sw846/pdfs/3060a.pdf (accessed Oct, 2011)

[12]. R.J. Vitale, G.R. Mussoline, J.C. Petura, and B.R. James, Hexavalent Chromium Extraction from Soils: Evaluation of an Alkaline Digestion Method, Journal of Environmental Quality, 23, 1994, 1249-1256.

[13]. New Jersey Chromium Workgroup Report. Chap. 4, 60-61. 